The Chittagong Univ. J. B. Sci., Vol. 5(1 \&2):77-89, 2010.

\title{
ISOLATION OF BACTERIA FROM VARIOUS SITES OF A PHARMACEUTICAL INDUSTRY AND EVALUATION OF THEIR SUSCEPTIBILITY TO SOME COMMONLY USED DISINFECTANTS.
}

\author{
MD. IMRAN HOSSAIN, S.M. MAHBUBUR RAHMAN, ROBIUL HASAN \\ BHUIYAN $^{1}$, MOHAMMAD SAYEDUL ISLAM ${ }^{1}$, A. M. MASUDUL AZAD \\ CHOWDHURY $^{2}$ AND MOHAMMAD ALAUDDIN ${ }^{1 *}$. \\ Department of ${ }^{1}$ Biochemistry \& Molecular Biology and ${ }^{2}$ Genetic Engineering \& Biotechnology , \\ University of Chittagong, Chittagong-4331, Bangladesh. \\ Biotechnology and Genetic Engineering Discipline, Khulna University, Bangladesh.
}

\begin{abstract}
The microbiological quality of air, surface and working personnel in a pharmaceutical industry was investigated. Bacterial isolates recovered from the processing environment were also identified. Phenol co-efficient of commonly used disinfectants such as sodium hypochlorite, savlon (chlorhexidine gluconate $0.3 \% \mathrm{w} / \mathrm{v}$ and cetrimide $3 \% \mathrm{w} / \mathrm{v}$ ), ethanol, methanol and isopropyl alcohol were determined using standard methods against the most predominant organisms. This study reveals that the personnel involved in manufacturing were the main source of contamination and the common organisms found from samples of air, surface, and working personnel monitoring area were Staphylococcus sp., Pseudomonas sp. and Escherichia sp. Among the used disinfectants of this study, sodium hypochlorite showed the highest potency. Phenol coefficient of sodium hypochlorite, savlon, isopropyl alcohol, methanol and ethanol were 5.55 and 4.44; 2.77 and 2.22; 0.22 and 0.33; 0.33 and $0.44 ; 0.11$ and 0.16 for Staphylococcus sp. and Pseudomonas sp., respectively. To reduce the risk of contamination, working personnel should follow the rules of cGMP (current good manufacturing protocol) and the disinfectants should be used in appropriate concentration for the beneficial cost effect of the pharmaceutical industry and also for a clean environment.
\end{abstract}

Key words: Disinfectant, Susceptibility, Bacteria.

* Corresponding author 
HOSSAIN ET AL.

\section{INTRODUCTION}

With the development of healthcare infrastructure and increase of health awareness, pharmaceutical sectors have become one of the top priorities in today's production world (Bashar et al. 2008). In Bangladesh, it is also a fast growing sector that contributes as import substitutes and also covers 95 percent of local demand being country's second largest tax payer. During the fiscal year 2002-2003, the earning from pharmaceutical exports stood at US\$10 million covering 52 countries. Approximately 75,000 skilled and unskilled people are associated in this sector (B.B.S. 2002 and Bhuiyan et al. 2011). Maintenance of appropriate quality of pharmaceutical product is considered vital for achieving success in the global trade. But one of the major problems in the pharmaceutical industry, especially during long production runs, is keeping contaminant microorganisms out of the production area. Contaminant bacteria, it seems, always multiply fast and rapidly turn a clean production run into a nasty mess. Moreover, when rogue bacteria go on a rampage, high cleanup cost, disrupted production schedule and most important-lost revenue will be faced. For these microbiological concerns in pharmaceutical product, manufactures continue to challenge those associated with their production. The microbiological quality of pharmaceutical products is greatly influenced by the environment in which they are manufactured (Hossain et al. 2004). With the exception of preparations that are terminally sterilized in their final container, the micro flora of the final product may represent contaminants from the atmosphere, from the personnel operating the process, from the raw materials, from the equipment with which it has been made, or from the final container into which it has been packed and stored. So, environmental control is an absolute necessity for manufacturing quality pharmaceutical products.

Environmental monitoring represents a critical process in the manufacture, especially those manufactured within highly controlled clean room conditions. The programme includes monitoring of air, personnel and surfaces and to meet regulatory authority requirements. Air monitoring is a critical component of the environmental monitoring programme of any pharmaceutical manufacturer. It is also a Good Manufacturing Practice (GMP) requirement that provides information on the quality of the processing environment during manufacturing and enables the study of microbiological air quality trends. So, air contamination control is an essential part of a global environmental monitoring approach. Surfaces also contain many microorganisms that can contaminate 


\section{BACTERIA FROM VARIOUS SITES OF A PHARMACEUTICAL INDUSTRY}

manufacturing process. Surface monitoring is performed to assess the level of microbial load on floors, walls, equipment, etc. Antiseptics and disinfectants are used extensively in pharmaceuticals and other health care settings for a variety of topical and hard-surface applications. In particular, they are an essential part of infection control practices and aid in the prevention of nosocomial infections (Larson 1996 and Rutala 1995).

In this study we investigated the various sources and types of microbial contamination in different production areas of a pharmaceutical industry. Some commonly used disinfectants were used to study their efficacy against the major contaminants isolated from production areas. The objectives of our study were to obtain representative estimates of bioburden, to find out the potential sources of contamination, to isolate and identify various bacteria associated with contamination of manufacturing area and to evaluate the potency of different disinfectants used in pharmaceuticals by phenol co-efficient technique.

\section{MATERIALS AND METHODS}

\section{Sampling procedure}

The microorganisms were collected from STA and other surface equipments and personnel. For air-borne microorganism, slit-to-agar air sampling100 air sampler and for surface equipment and personnel presterilized settle plates were used. Personal changing room, material room, internal corridor, liquid filling and sealing room, weighing room, solution preparation room, bottle packing room and bottle packing extension room were selected for air-borne microorganism. Microorganisms were also collected from surface equipment and different places such as personnel room wall/floor, material room wall/floor, clean corridor wall/floor, weighing room wall/floor, solution preparation room wall/floor. The frequency of sampling was once in a week and continued for five weeks (Lund 1994). In case of slit-to-agar (STA) air sampler, the sampling time was $1 \mathrm{~min}$. In case of STA sampling, the air sampling was obtained through a standard slit from three different places of the sampling site under which the petridish containing recommended media was placed to get the average results. The plate was then covered and placed in plastic container with lid at $37^{\circ} \mathrm{C}$ for 3 days. In case of surface equipment and personnel sampling by swab test, 30 grams of tryptone soya broth (TSB) and 40 gm of tryptone soya agar (TSA) were suspended in 1000 $\mathrm{ml}$ distilled water and boiled to dissolve the medium completely. 
HOSSAIN ET AL.

\section{Growth media}

Different commercial media were used for the isolation and identification of the microorganism including casein soyabean digest agar (CASO), MacConkey agar (MAC), microbial content test agar (MCT), mannitol salt agar (MSA), cetrimide agar and sabouraud dextrose agar (SDA).

\section{Estimation of total microbial count in the manufacturing area}

Total microbial count was expressed as colony forming units (cfu) per plate for MAS 100 air sampler. The air was graded as Grade A, B, C and D based on the maximum number of particles of $0.5 \mu \mathrm{m}$ per $\mathrm{m}^{3}$ for $3500,35000,350000$ and 3500000 respectively.

\section{Identification, screening and biochemical analysis of the bacterial strains}

Bacterial isolates recovered from the pharmaceutical processing environment were identified using the following protocol. To investigate the morphological structure the dissimilar colonies were picked up with the help of sterile loop and each colony was streaked on to freshly prepared plate of the same medium and incubated at required temperature for $24 \mathrm{~h}$ or more. After incubation, discrete colonies were taken as isolates. The isolated organisms were then purified through repeated streaking on agar plates until a pure culture was obtained. The pure culture was subjected to Gram straining and observed under bright field light microscope according to the manual of methods for general bacteriology by American Society of Microbiology (Gerhardt et al. 1981). Cultural character of pure isolate was carefully studied after 24 or $48 \mathrm{~h}$ incubation. The shape, size, configuration, form, texture, consistency, opacity, pigment production of isolated colonies were observed and were recorded. The biochemical studies for the identification of isolate were performed by different tests such as catalase test, oxidase test, methyl red (MR) test, Voges-Proskauer test, citrate utilization test, fermentation of carbohydrate test according to the methods described in manual of methods for general bacteriology (Gerhardt et al. 1981).

\section{Evaluation of disinfectants by phenol coefficient}

Although a number of disinfectants are used in pharmaceutical company their quality of efficiency is not the same. We investigated the following disinfectants, sodium hypochlorite (NaOCI 5.50\%)(dilution rate=1:200; 1:400; 


\section{BACTERIA FROM VARIOUS SITES OF A PHARMACEUTICAL INDUSTRY}

1:500), Savlon (chlorhexidine gluconate $0.3 \% \mathrm{w} / \mathrm{v}$ and cetrimide $3 \% \mathrm{w} / \mathrm{v}$ ) (dilution rate $=1: 150 ; 1: 200 ; 1: 250$ ), isopropyl alcohol (dilution rate $=1: 10 ; 1: 20$; $1: 30$ ), methanol (dilution rate $=1: 20 ; 1: 30 ; 1: 40$ ) and ethanol (dilution rate $=1: 5$; $1: 10 ; 1: 15)$. To evaluate the disinfectants, a series of dilution of phenol and the experimental antimicrobial agents were prepared in sterile tube. Viable test bacteria (Staphylococcus sp. and Pseudomonas sp.) were then inoculated into each of the test tubes of disinfectant. One full loop from each of the test tubes containing the disinfectants and microorganism was transferred at intervals of 5 and $10 \mathrm{~min}$ into appropriately labeled nutrient broth and were incubated for $48 \mathrm{~h}$ at $37^{\circ} \mathrm{C}$. The highest dilution of the antimicrobial agent and of phenol that effectively killed the test organism within 10 min exposure was used to compute the phenol coefficient that can be expressed as below (Lund 1994):

\section{1 / [Effective dilution of test antimicrobial agent]}

$1 /$ [Effective dilution of phenol]

\section{RESULTS AND DISCUSSION}

Air borne contamination rate of each location of the manufacturing area were monitored using MAS 100-air sampler over a five week period of the study time and microbial counts were expressed as $\mathrm{cfu} / \mathrm{m}^{3}$ for air sampler. The highest microbial load was found in the personnel changing room which is Grade D and The lowest load was found in the solution (oral liquid) preparation room, which is Grade C. The microbial load of other three Grade D areas such as material room, bottle packing room and bottle packing extension room were within the permitted limit. It was observed that the air borne contamination recovery by using MAS 100 air sampler, which had 100 liter air sampling capacity per minute, was higher than using the settle plates. In this case, the Grade D was within the recommended load limit of $500 \mathrm{cfu} / \mathrm{m}^{3}$ and also Grade $\mathrm{C}$ was within the recommended load limit of $100 \mathrm{cfu} / \mathrm{m}^{3}$. The microbial load of these recommended areas was within limit during investigation that has been mentioned in Figure 1. 
HOSSAIN ET AL.
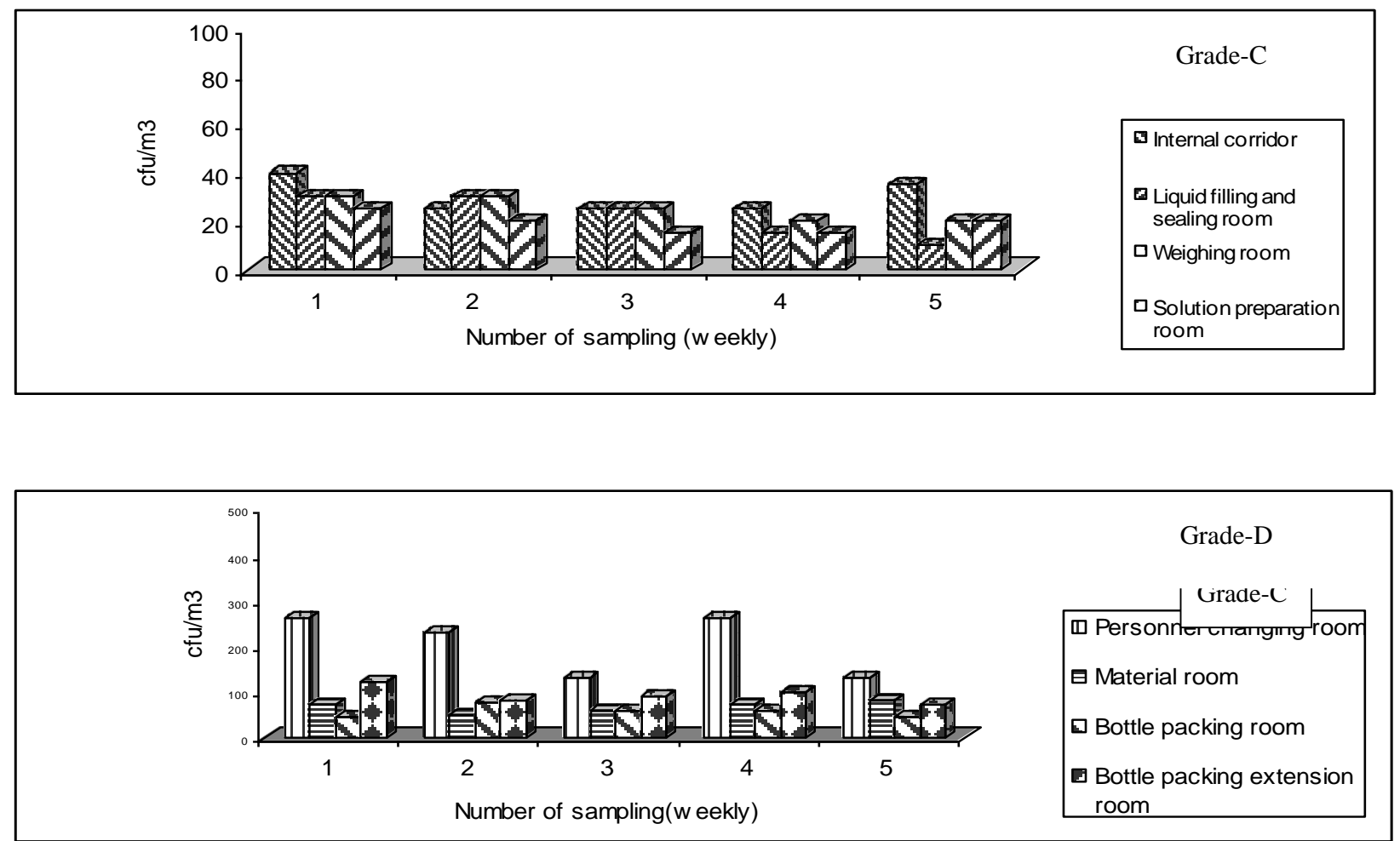

FIGURE 1: AVERAGE MICROBIAL COUNT IN MANUFACTURE AREA BY AIR SAMPLER METHOD [GRADE - C AND D].

Wall, floor and equipment were monitored using swab test method during the investigation period. It was observed that the microbial load of the floor was always higher than that of walls. The microbial loads of manufacturing area surfaces of Grade D and Grade C were $50 \mathrm{cfu} /$ contact plate and $25 \mathrm{cfu} /$ contact plate, respectively (USP-24; 2000). It was also observed that the highest microbial count was $41 \mathrm{cfu} /$ contact plate in bottle packing extension room floor and the lowest was $5 \mathrm{cfu} /$ contact plate observed in solution preparation room wall during this investigation (Figure 2. A, D). 


\section{BACTERIA FROM VARIOUS SITES OF A PHARMACEUTICAL INDUSTRY}

\section{SWAB TEST FOR FLOOR}
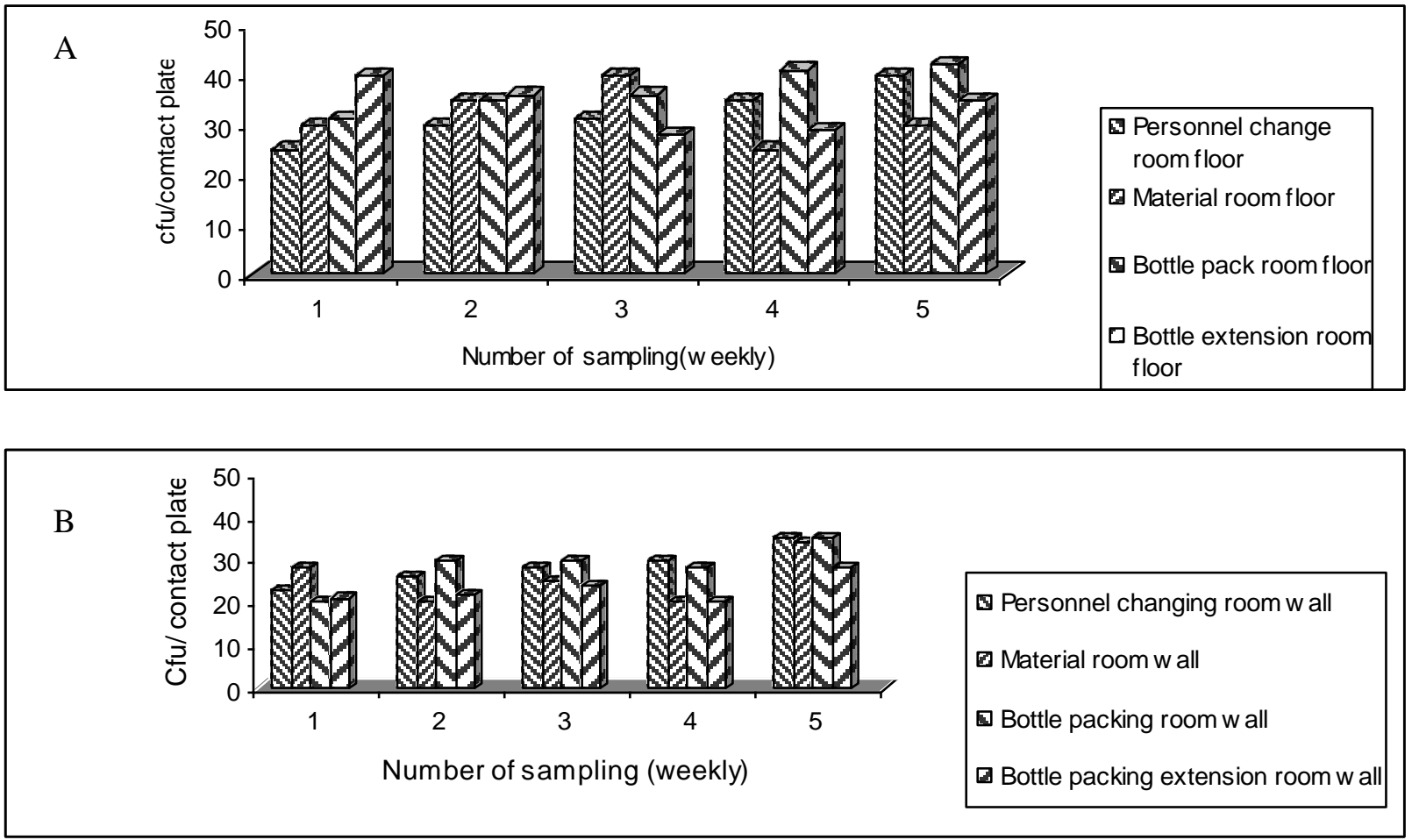

SWAB TEST FOR WALL

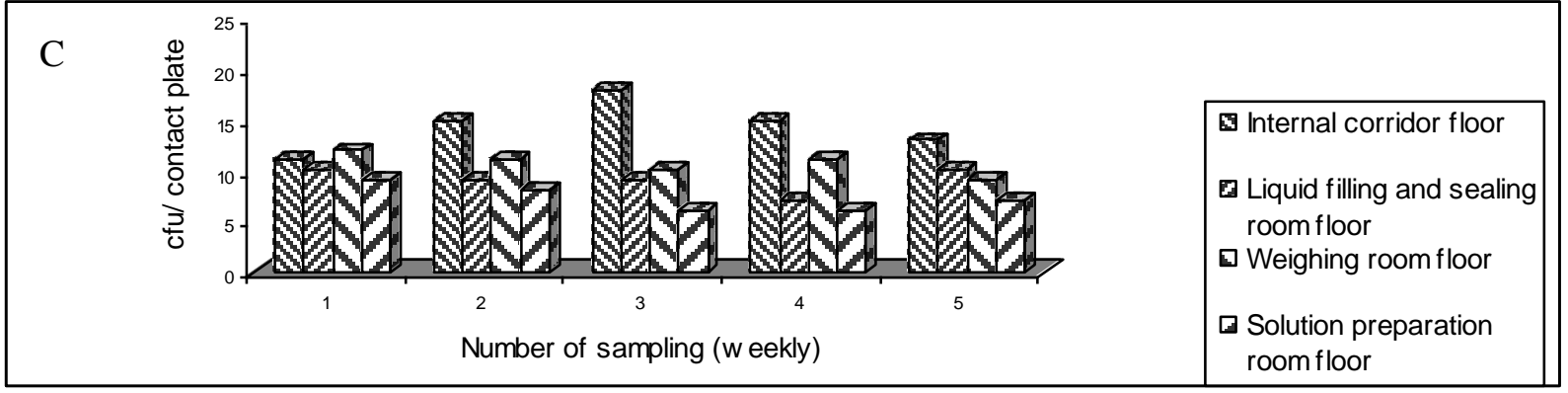

SWAB TEST FOR WALL 
HOSSAIN ET AL.

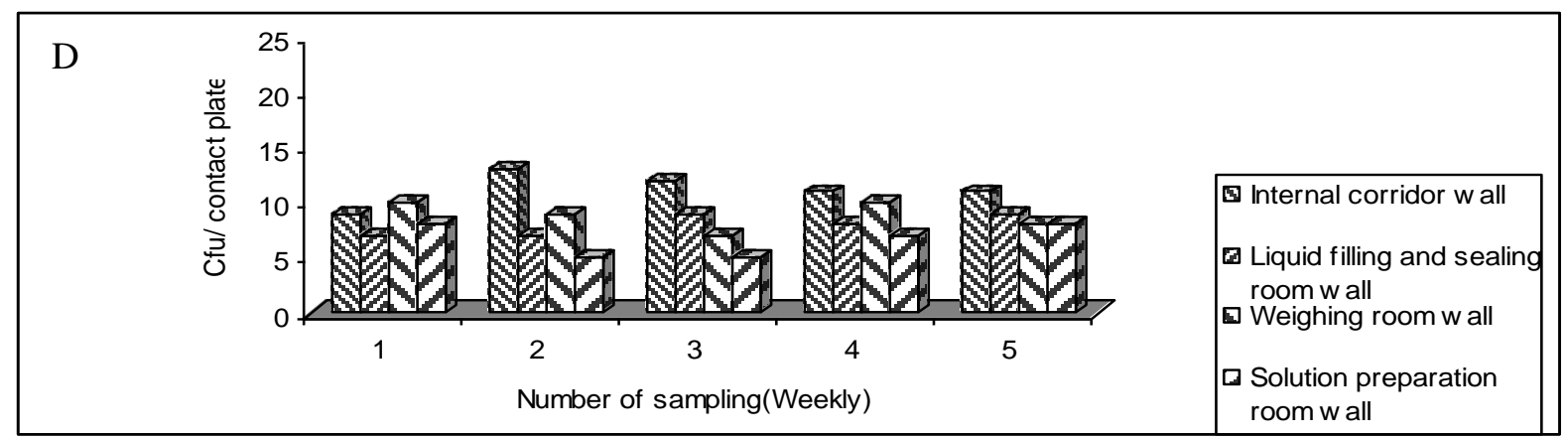

FIGURE 2: AVERAGE MICROBIAL COUNT IN MANUFACTURE AREA SURFACES USING SWAB TEST.

[A AND B INDICATE AVERAGE MICROBIAL COUNT IN FLOOR OF DIFFERENT AREA. C AND D INDICATE AVERAGE MICROBIAL COUNT IN WALL OF DIFFERENT AREA.]

Hand of the working personnel were monitored by swab test method. The result indicated that the microbial load of operators' hand who worked mainly in Grade D was relatively higher than the operators who worked in the Grade C. Here operator 1, 2 and 3 were working in a Grade D and operator 4 and 5 who were working in Grade $\mathrm{C}$ (Figure 3). The recommended limit of the microbial growth load of operators who worked in the grade- $\mathrm{C}$ and grade-D are $5 \mathrm{cfu} /$ contact plate and $20 \mathrm{cfu} /$ contact plate, respectively (USP-24, 2000).

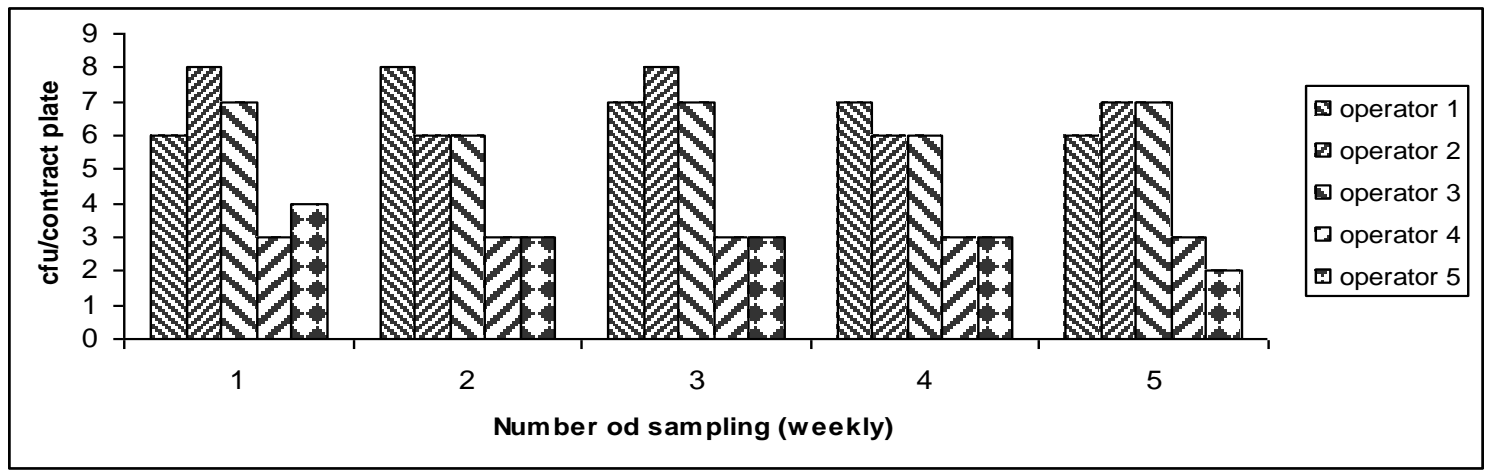

FIGURE 3: AVERAGE MICROBIAL COUNT IN MANUFACTURING PERSONNEL.

Twelve isolates, were frequently found by monitoring of air, surface and personnel. The isolate Am1, Am2, Am3 and Am4 were obtained from sampling of air using casein-soyabean digest agar medium (CASO). The isolate $\mathrm{Sm} 1, \mathrm{Sm} 2$, Sm3, Sm4 and Hm1, Hm2, Hm3, Hm4 were obtained from sampling of surface and personnel using microbial content test agar medium (MCT). Morphologically 


\section{BACTERIA FROM VARIOUS SITES OF A PHARMACEUTICAL INDUSTRY}

dissimilar colonies were found on different agar medium. Colony size, pigmentation, form, margin, elevation etc. were analyzed under different culture observation.

Gram staining was performed with all the different type of colonies obtained on the selective and differential medium. This helped in presumptive identification of the suspected organisms. Gram-positive cells have a thick peptidoglycan layer, whereas the peptidoglycan layer in Gram-negative cells is much thinner and surround by an outer lipid containing layers. The Gram reaction was performed for all different types of colonies observed. Different biochemical tests were performed for the isolates as shown in Table 1. With the help of Bergey's manual of determinative bacteriology (David and John 1994), the isolates were presumptively identified. Besides biochemical test, culture and morphological characteristics were also considered as special for identification.

TABLE 1: BIOCHEMICAL STUDIES OF THE ISOLATES.

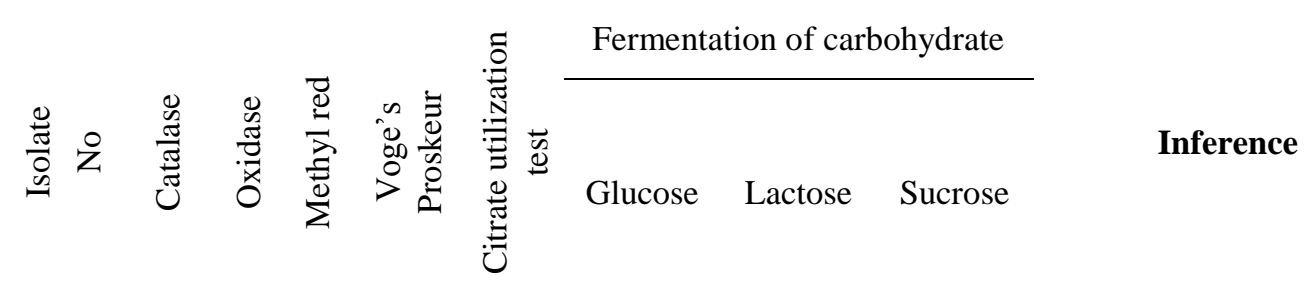

\begin{tabular}{|c|c|c|c|c|c|c|c|c|c|}
\hline $\mathrm{Am} 1$ & + & - & + & - & - & + & + & + & Staphylococcus sp. \\
\hline $\mathrm{Am} 2$ & + & - & + & - & - & + & + & + & Staphylococcus sp. \\
\hline Am3 & + & + & + & - & - & - & - & - & Pseudomonas sp. \\
\hline Am4 & + & - & + & - & - & + & + & + & Staphylococcus sp. \\
\hline Hm1 & + & + & + & - & - & - & - & - & Pseudomonas sp. \\
\hline $\mathrm{Hm} 2$ & + & - & + & - & - & + & + & + & Escherichia sp. \\
\hline $\mathrm{Hm} 3$ & + & - & + & - & - & + & + & + & Staphylococcus sp. \\
\hline $\mathrm{Hm} 4$ & + & - & + & - & - & + & + & + & Escherichia sp. \\
\hline Sm1 & + & - & + & - & - & + & + & + & Staphylococcus sp. \\
\hline Sm2 & + & + & + & - & - & - & - & - & Pseudomonas sp. \\
\hline Sm3 & + & - & + & - & - & + & + & + & Staphylococcus sp. \\
\hline $\mathrm{Sm} 4$ & + & + & + & - & - & - & - & - & Pseudomonas sp. \\
\hline
\end{tabular}

The current demands in pharmaceuticals industry for quality control and quality assurance have been driven by the aspiration to deliver consistently high quality and safe products to the customer. The prime responsibility for quality control lies with the manufacturing process. Careful microbial control of the processing environment has importance specially in aseptic processing. 
In the present study, the air borne contamination rates of each location of the manufacturing area was investigated. The microbial load of personnel changing room is highest than the other room of Grade-D and all working personnel moved through this area. The microbial load of other three Grade-D rooms such as material room, bottle packaging room and bottle packaging extension room was in permissible limit. The microbial load of liquid preparation room did not exceed the recommended limit during the five-week investigation period. The presence of higher number of working personnel and the working machinery may be the prime cause of highest contamination rate. The air borne contamination was beings also recovered using MAS 100 air sampler, which has 100-litre air sampling capacity per minute. The microbial count of air can be reduced by variety of ways but filtration is commonly used. High efficiency particulate filter (HEPA) is used for controlling the air borne contamination. Chemical agents such as formaldehyde gas are also effective but it has irritating properties (Hugo and Russell 1982). Fumigation is another process where formaldehyde and $\mathrm{KMnO}_{4}$ solution are used to control the air borne contamination.

Microorganism may be transferred to a product from working surfaces. So monitoring of surface and instrument is an important aspect as routin practice in the pharmaceutical industry (Dave 1991). This study revealed that the microbial loads of floor of manufacturing area are higher than that of walls. The highest count (41 cfu/ contact plate) was observed in the floor of bottle packing extension room and lowest (6 cfu/contact plates) was observed in the floor of solution preparation room. The surface integrity of floor of most of the areas was not maintained properly and these contribute to higher count. Most inadvertent contamination found in the manufacture area originating from the hands of the working personnel. Our study revealed that the microbial load of hands of operator (1,2 and 3) was higher than those worked in the grade-D area and the lowest growth was found in hands operator 4 and 5 who worked in grade-C. Another aspect of the study was to identify the major contaminating bacteria in a pharmaceutical processing environment. Twelve bacterial strains, which were frequently found by monitoring the air and surface samples, the cultural characteristics of the isolates on different selective and differential agar medium were also observed and recorded.

There were great variations in cultural characteristic among the isolates. Colony size, pigmentation, form, margin, and elevation varied. Some isolates differed in their cultural characteristic but their biochemical character has placed 


\section{BACTERIA FROM VARIOUS SITES OF A PHARMACEUTICAL INDUSTRY}

them in standard categories. Microscopic examination was performed for all the isolated and various biochemical tests were performed for their identification. Then, with the help of Bergey's Manual of Determinative Bacteriology (David and John 1994), the isolates were identified. Besides biochemical test morphological characteristic were also considered as special importance for identification. The bacterial isolates found in this study were staphylococcus sp., Pseudomonas sp., Escherichia sp. and Staphylococcus sp. are natural skin flora. It is common in the hands and face. The nasal passage may also contain large number of Staphylococcus spp. (Hugo and Russell 1982). So it can be easily transferred from the operator. Free-living opportunistic pathogen such as Pseudomonas sp. can normally be found in all wet sites, such as grains, skins, and taps. Cleaning equipment such as mops, buckets, cloths may be responsible for spreading the pseudomonas sp. (Baird et al. 2000). It is also reported that static water contains Pseudomonas sp. so it can be spreaded to the manufacturing area from any of these sources. Escherichia sp. was found from the samples isolated from operator's hands. The prime reason may be that the operators did not wash their hands properly after returning from bathroom. Steptococuss sp. is most common organism secreted during normal respiratory function and speech (Hugo and Russell 1982). So, it may be also distributed from the operators.

In this study, the potency of five commonly used disinfectants used in the pharmaceutical industry such as sodium hypochlorite, savlon, isopropyl alcohol, ethanol and methanol were determined by phenol coefficient technique against the most predominant Staphylococcus sp. and Pseudomonas sp. The value of the phenol co-efficient ranged from 5.55 to 0.11 . Phenol coefficient of sodium hypochlorite for Staphylococcus sp. and Pseudomonas sp. were 5.55 and 4.44; for savlon 2.77 and 2.22; for isopropyl alcohol 0.22 and 0.33 ; for ethanol 0.11 and 0.16; for methanol 0.33 and 0.44 (Table 2). It was also found that sodium hypochlorite had the highest disinfectant capacity where savlon, isopropyl alcohol, methanol and ethanol had gradually decreasing disinfectant activity. 
HOSSAIN ET AL.

TABLE 2: DETERMINATION OF PHENOL CO-EFFICIENT OF DIFFERENT DISINFECTANTS FOR STAPHYLOCOCCUS SP. AND PSEUDOMONAS SP.

\begin{tabular}{|c|c|c|c|c|c|c|c|}
\hline \multirow{2}{*}{$\begin{array}{c}\text { Name of } \\
\text { disinfectant }\end{array}$} & \multirow{2}{*}{ Dilution } & \multicolumn{2}{|c|}{$\begin{array}{c}\text { Growth in } \\
\text { subculture for } \\
\text { Staphylococcus } \\
\text { sp. } \\
\end{array}$} & \multirow{2}{*}{ 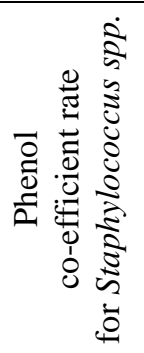 } & \multicolumn{2}{|c|}{$\begin{array}{c}\text { Growth in } \\
\text { subculture for } \\
\text { Pseudomonas } \\
\text { sp. }\end{array}$} & \multirow{2}{*}{ 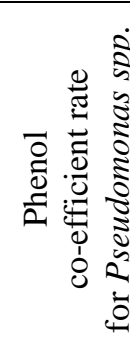 } \\
\hline & & n $\underset{\Xi}{\stackrel{\Xi}{E}}$ & $\bigcirc \stackrel{\stackrel{\Xi}{\Xi}}{. \Xi}$ & & $\sum_{n}^{\stackrel{\Xi}{\Xi}}$ & ○ & \\
\hline \multirow{3}{*}{$\begin{array}{l}\mathrm{NaOCI} \\
(5.50 \%)\end{array}$} & $1: 200$ & - & - & \multirow{3}{*}{5.55} & - & - & \multirow{3}{*}{4.44} \\
\hline & $1: 400$ & - & - & & - & + & \\
\hline & $1: 500$ & + & - & & - & - & \\
\hline \multirow{3}{*}{ Savlon } & $1: 150$ & - & - & \multirow{3}{*}{2.77} & - & - & \multirow{3}{*}{2.22} \\
\hline & $1: 200$ & - & - & & + & - & \\
\hline & $1: 250$ & + & - & & + & + & \\
\hline \multirow{3}{*}{$\begin{array}{l}\text { Isopropyle } \\
\text { Alcohole }\end{array}$} & $1: 10$ & - & - & \multirow{3}{*}{0.22} & - & - & \multirow{3}{*}{0.33} \\
\hline & $1: 20$ & - & + & & - & - & \\
\hline & $1: 30$ & + & + & & - & + & \\
\hline \multirow{3}{*}{ Ethanol } & $1: 5$ & - & - & \multirow{3}{*}{0.11} & - & - & \multirow{3}{*}{0.16} \\
\hline & $1: 10$ & - & + & & - & - & \\
\hline & $1: 15$ & + & + & & - & + & \\
\hline \multirow{3}{*}{ Methanol } & $1: 20$ & - & - & \multirow{3}{*}{0.33} & - & - & \multirow{3}{*}{0.44} \\
\hline & $1: 30$ & - & + & & - & - & \\
\hline & $1: 40$ & + & + & & + & + & \\
\hline \multirow{3}{*}{ Phenol } & $1: 70$ & - & - & \multirow{3}{*}{1.0} & - & - & \multirow{3}{*}{1.0} \\
\hline & $1: 80$ & - & - & & - & - & \\
\hline & $1: 90$ & + & - & & + & - & \\
\hline
\end{tabular}

This study also revealed that inefficiency from disinfectants misuse is widespread in pharmaceutical industry. Higher concentration of different disinfectants is not necessarily required. So, dilution of the disinfectants to the appropriate concentration is a great importance, research should be continued to search for the best disinfectant with all the desirable properties and appropriate concentration. 
BACTERIA FROM VARIOUS SITES OF A PHARMACEUTICAL INDUSTRY

\section{REFERENCES}

BAIRD, R. M., HODGES, N. A. AND DENYER, S. P. 2000. Hand-book of Microbiological Quality Control: Pharmaceuticals and Medical Devices. Taylor \& Francis. London. Pp. 245-262.

BASHAR, T., SHUROVI, K. M. AND DILSHAD, S. 2008. An improved in vitro pyrogen test to detect the presence of endotoxin containing bacterisa using Limulus Amoebocyte Lysate Assay from Pharmaceutical raw product. S. J. Pharm. Sci. 1(1\&2):76-79.

B.B.S. (BANGLADESH BUREAU OF STATISTICS) 2004, Bangladesh Bank, Drugs Administration, Bangladesh Aushad Silpa Samity Bulletin, Bangladesh Pharmaceutical Index 3Q2004. Pp. 77-86.

BHUIYAN, M. A. R., MANIRUZAMAN AND SULTANA, S. 2011. Analysis of Pharmaceutical industry of Bangladesh. Bangladesh Res. Pub. J. 5(2): 142-156.

DAVE, M. 1991. A practical guide to disinfectants. J. Pharm. Sci. 8: 19-23.

DAVID, H. B. AND JOHN, G. H. 1994. Bergey's manual of determinative bacteriology. Williams \& Wilkins company, Baltimore. Pp. 1221-1234.

GERHARDT, P., MURRAY, R. G. E., WOOD, W. A. AND KRIEG, N. R. 1981. Manual of Methods For General Bacteriology. American Society for Microbiology, Washington. Pp. 267-281.

HOSSAIN, M., SHAMIM, A. AND RAHMAN, M. Z. 2004. Quantitative examination of aerobic bacteria and fungi in locally available antacid suspension and possible contamination by specified bacteria. Pak. J. Bio. Sci. 7(11): 2014-2017.

HUGO, W. B. AND RUSSELL, A. D. 1992. Pharmaceutical Microbiology. $5^{\text {th }}$ edition. Blackwell Scientific Publications. Oxford. Pp. 314-336.

LARSON, E. L. 1996. Antiseptics. APIC Infection Control \& Applied Epidemiology: Principles \& Practices. In R. N. Olmstad (ed.), MosbyYear Book, Inc., St. Louis, Mo. pp. 19-1, -19-7, G1-G17.

LUND, W. 1994. Pharmaceutical Codex: Principles and Practice of Pharmaceutics. $12^{\text {th }}$ ed. Pharmaceutical Press. London. Pp. 509-526.

RUTALA, W. A. 1995. APIC guidelines for selection and use of disinfectants. Am. J. Infect Control. 23:313-342.

Manuscript received on 8. 12. 2010; Accepted on 29.9.11

The Chittagong University Journal of Biological Sciences, Vol. 5 (1 \& 2). Page No: 77-89 